\title{
THE APRIL MEETING IN NEW YORK
}

The four hundred fifteenth meeting of the American Mathematical Society was held at Columbia University on Friday and Saturday, April 26-27, 1946. The attendance included the following two hundred eighty-eight members of the Society:

C. R. Adams, C. F. Adler, R. P. Agnew, R. L. Anderson, R. G. Archibald, R. F. Arens, H. A. Arnold, L. A. Aroian, K. J. Arrow, R. N. Ascher, Silvio Aurora, M. C. Ayer, E. G. Baker, Valentine Bargmann, P. T. Bateman, Richard Bellman, A. A. Bennett, Stefan Bergman, D. L. Bernstein, Felix Bernstein, Lipman Bers, Garrett Birkhoff, M. L. Boas, R. P. Boas, Salomon Bochner, G. L. Bolton, Samuel Borofsky, S. G. Bourne, A. H. Bowker, C. B. Boyer, A. T. Brauer, Richard Brauer, A. B. Brown, G. W. Brown, E. F. Buck, R. C. Buck, R. S. Burington, Herbert Busemann, Hobart Bushey, J. H. Bushey, S. S. Cairns, H. H. Campaigne, W. M. Chen, Alonzo Church, Paul Civin, R. F. Clippinger, I. S. Cohen, R. M. Cohn, Nancy Cole, H. R. Cooley, T. F. Cope, Richard Courant, Franco Croci, H. B. Curry, J. H. Curtiss, M. D. Darkow, Norman Davids, L. S. Dederick, C. R. DePrima, C. L. Dolph, H. L. Dorwart, C. H. Dowker, Arnold Dresden, Jacques Dutka, Bernard Epstein, G. C. Evans, W. H. Fagerstrom, Ky Fan, Herbert Federer, J. M. Feld, Will Feller, A. D. Fialkow, N. J. Fine, W. B. Fite, R. M. Foster, F. H. Fowler, G. A. Foyle, A. A. Fraenkel, Gerald Freilich, Bernard Friedman, K. O. Friedrichs, Orrin Frink, R. E. Fullerton, A. S. Galbraith, G. N. Garrison, B. H. Gere, David Gilbarg, B. P. Gill, Leonard Gillman, R. E. Gilman, A. M. Gleason, Casper Goffman, A. W. Goodman, R. O. Goodman, Saul Gorn, L. M. Graves, Leonard Greenstone, Lewis Greenwald, R. E. Greenwood, George Grossman, E. J. Gumbel, D. W. Hall, F. C. Hall, Marshall Hall, P. R. Halmos, Frank Harary, Philip Hartman, V. A. Harvey, Ernest Hawkins, K. E. Hazard, M. H. Heins, Olaf Helmer, T. H. Hildebrandt, Einar Hille, T. R. Hollcroft, Harold Hotelling, S. E. Hotelling, E. M. Hull, Witold Hurewicz, (L.) C. Hutchinson, S. A. Joffe, Fritz John, R. E. Johnson, Aida Kalish, Edward Kasner, M. E. Kellar, L. S. Kennison, H. S. Kieval, S. A. Kiss, J. W. Kitchens, J. R. Kline, Morris Kline, E. G. Kogbetliantz, E. R. Kolchin, B. O. Koopman, M. E. Ladue, V. V. Latshaw, J. R. Lee, Solomon Lefschetz, D. H. Lehmer, A. M. A. Lehr, M. E. Levenson, Howard Levi, Madeline Levin, Norman Levinson, J. V. Lewis, Marie Litzinger, E. R. Lorch, A. N. Lowan, C. I. Lubin, L. A. MacColl, G. W. Mackey, H. M. MacNeille, H. F. MacNeish, Murray Mannos, A. J. Maria, Imanuel Marx, S. P. Mead, H. L. Meyer, D. S. Miller, Deane Montgomery, T. W. Moore, Vladimir Morkovin, D. J. Morrow, Marston Morse, G. W. Mullins, F. J. Murray, D. S. Nathan, C. A. Nelson, O. E. Neugebauer, Morris Newman, G. E. Noether, P. B. Norman, L. R. Norwood, V. M. Noyes, C. O. Oakley, A. F. O’Neill, J. C. Oxtoby, J. S. Oxtoby, A. M. Peiser, A. J. Penico, Everett Pitcher, Harry Polachek, Harry Pollard, E. L. Post, William Prager, Walter Prenowitz, M. H. Protter, R. G. Putnam, H. W. Reddick, Mina Rees, R. W. Rempfer, Moses Richardson, R. G. D. Richardson, C. E. Rickart, John Riordan, J. F. Ritt, E. K. Ritter, J. H. Roberts, M. S. Robertson, Robin Robinson, S. L. Robinson, I. H. Rose, Ira Rosenbaum, J. H. Rosenbloom, P. C. Rosenbloom, Raphael Salem, John Salerno, H. E. Salzer, Hans Samelson, Arthur Sard, L. J. Savage, S. A. Shaaf, Robert Schatten, Henry Scheffé, Lowell Schoenfeld, Abraham Schwartz, J. B. Secrist, C. W. Seekins, I. E. Segal, Hyman Serbin, C. E. Shannon, C. B. Shapira, I. M. Sheffer, Max Shiffman, L. P. Siceloff, 
James Singer, D. M. Smiley, M. F. Smiley, Henry E. Smith, P. A. Smith, W. M. Smith, Herbert Solomon, V. E. Spencer, E. R. Stabler, E. P. Starke, Fritz Steinhardt, E. G. Straus, L. M. Straus, R. C. Strodt, W. C. Strodt, A. C. Sugar, Fred Supnick, Irving Sussman, Otto Szász, J. H. Taylor, Feodor Theilheimer, J. M. Thomas, L. F. Tolle, Hing Tong, Leonard Tornheim, C. A. Truesdell, Y. W. Tschen, H. F. Tuan, A. W. Tucker, Bryant Tuckerman, J. W. Tukey, Annita Tuller, S. M. Ulam, W. R. Utz, H. S. Vandiver, H. E. Vansant, Oswald Veblen, R. J. Walker, A. D. Wallace, R. M. Walter, W. R. Wasow, Alan Wayne, J. V. Wehausen, Harry Weingarten, Alexander Weinstein, M. E. Wells, V. H. Wells, R. A. Wetzel, F. J. Weyl, George Whaples, A. P. Wheeler, G. W. Whitehead, S. S. Wilks, C. S. Williams, John Williamson, Clement Winston, Z. S. Wurtele, Bertram Yood, H. J. Zimmerberg, Leo Zippin, O. J. Zobel, M. F. Zucker, Antoni Zygmund.

The meeting opened Friday afternoon at $1: 30$ with an address on The triangulation problem and its role in analysis by Professor S. S. Cairns. Professor Solomon Lefschetz presided. President T. H. Hildebrandt presided at the Symposium in which Professor Marston Morse gave an address on Topological methods in the theory of functions of a single complex variable. Dr. M. H. Heins led the discussion.

On Saturday morning there were three sections for research papers: Analysis in which Dean R. G. D. Richardson presided, Geometry and Topology in which Professor A. D. Wallace presided, and Algebra, Statistics, etc., in which Professor Orrin Frink presided.

At 2:30 P.M. Saturday Professor Richard Brauer gave an address On the arithmetics of algebras. Professor Emeritus W. B. Fite presided.

The Council met on Friday at 4:30 P.M. in Havemeyer Hall.

The Secretary announced the election of the following one hundred and eighty persons to ordinary membership in the Society:

Professor Albert A. Aardal, Wartburg College, Waverly, Iowa;

Dr. James C. Abbott, Annapolis, Md.;

Professor William Franklin Adams, University of Alabama;

Mr. Merle M. Andrew, Massachusetts Institute of Technology;

Mr. Cloyd Payne Armbrister, Concord College, Athens, W. Va.;

Professor Homer Leon Arnold, Humboldt State College, Arcata, Calif.;

Professor Helen Barton, Woman's College, University of North Carolina;

Miss Ruby Baxter, Frances Shimer College, Mount Carroll, Ill.;

Professor Alice Knisely Bell, Fresno State College;

Mr. Edmund Callis Berkeley, Lieutenant Commander, U.S.N.R.;

Mr. Salvatore Dante Bernardi, University of Illinois;

Professor Arthur Bernhart, University of Oklahoma;

Mr. William Werner Boone, Princeton University;

Dr. Paul Boschan, The Econometric Institute, Inc., New York, N. Y.;

Mr. Nelson Allen Brigham, Arlington, N. J.;

Dr. Louis Francis Brown, Hollywood, Calif;

Professor A. C. Burdette, University of California, Davis, Calif.;

Mr. Robert C. Byers, Institute of Optics, University of Rochester;

Mr. George Overall Caldwell, Rust College, Holly Springs, Miss.; 
Sister Rose Gertrude Calloway, Washington, D. C.;

Dr. Bernardo Guillermo Cap6, Agricultural Experimental Station, Río Piedras, Puerto Rico;

Professor Francis L. Celauro, Lehigh University;

Professor Reynaldo Pedro Cesco, University of La Plata;

Mr. Chester Ray Clark, McKinley High School, Washington, D. C.;

Professor John R. Clark, Teachers College, Columbia University;

Mr. Charles Greenleaf Cloudman, Ebasco International Corp., New York, N. Y.;

Mr. Alberto Dias Coimbra, Lyceum de Coimbra, Coimbra, Portugal;

Professor William Atlee Conrad, U. S. Naval Academy;

Mr. E. Allen Cook, Office of Chief of Chemical Warfare Service, War Department;

Dr. Robert Cortell, College of the City of New York;

Dean Roger Flavius Cox, John Brown University, Siloam Springs, Ark.;

Miss Dorothy Irene Coyne, Pine Cobble School, Williamstown, Mass.;

Miss Kathleen Creagh, Waller Branch High School, Chicago, Ill.;

Professor James Thomas Culbertson, Southwestern University, Georgetown, Tex.;

Professor Charles Harold Douglas, Catawba College, Salisbury, N. C.;

Mr. Donald Gordon Duncan, University of British Columbia;

Mr. Walter George Dyer, Lieutenant (j.g.), U.S.C.G.;

Professor Anthony Joseph Eiardi, Boston College;

Mr. William Ralph Eikelberger, U. S. Naval Academy;

Miss Jane Lee Evans, Old Trail School, Akron, Ohio;

Miss Meta M. Ewing, Bay City Junior College, Bay City, Mich.;

Reverend Fred J. Fischer, DePaul University;

Professor Immanuel C. Fischer, University of Minnesota;

Mr. William Thompson Fishback, Radiation Laboratory, Massachusetts Institute of

Technology;

Professor A. A. Fraenkel, Hebrew University, Jerusalem, Palestine;

Mr. Norman Saffrey Free, Mount Royal College, Calgary, Alberta, Canada;

Sister M. Elizabeth Frisch, Villa Madonna College, Covington, Ky.;

Professor Abel Gauthier, University of Montreal;

Miss Florence Evelyn Gerhardt, University of Wisconsin;

Mr. Robert Anthony Joseph Gildea, Brown University;

Mr. Malcolm Elisha Gillis, University of Tennessee;

Mr. Homer T. Gittings, Jr., Naval Ordnance Laboratory, Washington, D. C.;

Mr. Jacob Kopel Goldhaber, University of Wisconsin;

Dr. Louis Goldstein, Division of War Research, O.S.R.D., New York, N. Y.;

Mr. David Martin Good, Princeton University;

Professor Morris J. Gottlieb, Washington University;

Professor Pierre Lucien Gregoire, University of Montreal;

Professor Lino Gabriel Gutierrez, University of Havana;

Professor William A. Hallam, West Virginia Wesleyan College;

Mr. Ray Irvine Hardin, New York, N. Y.;

Mr. Lyman John Harris, Aluminum Company of America;

Mr. Charles Edward Harrison, Technisonic Laboratory, St. Louis, Mo.;

Miss Bertha Irene Hart, Ballistics Research Laboratory, Aberdeen Proving Ground, Md.;

Miss Veronica Andrea Harvey, St. Joseph's College for Women, Brooklyn, N. Y.;

Mr. Manuel Herschdorfer, Amherst College;

Professor Paul Otto Hoffmann, Newark College of Engineering, Newark, N. J.; 
Mr. William Julian Jaffe, Newark College of Engineering, Newark, N. J.;

Mr. Lawrence Gabriel Jones, Radiation Laboratory, Massachusetts Institute of Technology;

Miss Margaret Joseph, Shorewood High School, Milwaukee, Wis.;

Dr. Charles Hillis Kaiser, Bennington College;

Miss Bruria Kaufman, Philadelphia, Pa.;

Mr. Peter John Kiernan, U. S. Military Academy;

Professor Allen Lewis King, Department of Physics, Dartmouth College;

Professor Lyman Coleman Knight, Muskingum College, New Concord, Ohio;

Mr. Paul J. Kopp, Major, Chemical Warfare Service, U.S.A.;

Dr. Waclaw Kozakiewicz, University of Saskatchewan;

Dr. Maria Zbigniew Krzywoblocki, Palo Alto, Calif.;

Miss Dorothy B. Landau, Junior High School 81, New York, N. Y.;

Miss Lucy Anne La Sala, O.S.R.D., New York, N. Y.;

Professor Lloyd Laurits Lassen, North Texas Agricultural College, Arlington, Tex.;

Mr. Oliver L. Lattimore, Texas College, Tyler, Tex.;

Dr. Nathan Lazar, Teachers College, Columbia University;

Mr. William John Lee, San Benito County High School and Junior College, Hollister, Calif.;

Mr. Walter Gilbert Leight, Captain, U.S.A.;

Professor W. H. Lipscombe, University of Akron;

Professor Brendan A. Lynch, Siena College, Loudonville, N. Y.;

Miss Ethelyne L. McBee, Bureau of Human Nutrition and Home Economics, U. S. Department of Agriculture, Washington, D. C.;

Miss Jessie Irene McClune, United Aircraft Corp., East Hartford, Conn.;

Mr. William Straight McCulley, University of Texas;

Professor Kenneth Madison McDonald, Judson College, Marion, Ala.;

Professor Gordon Richey Magee, University of Western Ontario;

Professor Dis Maly, Rensselaer Polytechnic Institute, Troy, N. Y.;

Mr. Alvin Stuart Mancib, West Somerville, Mass.;

Professor Armin William Manning, Concordia Collegiate Institute, Bronxville, N. Y.;

Professor Guy Ernest March, South Dakota School of Mines;

Reverend Norbert Martin, St. Francis College, Loretto, Pa.;

Mr. Paul Meier, Princeton University;

Mr. Paul Theodore Mielke, Wabash College, Crawfordsville, Ind.;

Dr. Abraham Miller, Lieutenant Commander, U.S.N.R.;

Mr. William Edward Miller, New Jersey State Teachers College, Trenton, N. J.;

Professor Johann Mokre, Barat College, Lake Forest, Ill.;

Professor Lawrence Joseph Monville, John Carroll University, Cleveland, Ohio;

Mr. Morris Morduchow, Polytechnic Institute of Brooklyn;

Mr. George F. Morecroft, Metropolitan Life Insurance Company, New York, N. Y.;

Mr. William Daniel Morgan, Saint Paul, Minn.;

Sister Marie Jesse Morrison, Nazareth College, Nazareth, Mich.;

Miss Catherine E. Moser, Penn Hall, Chambersburg, Pa.;

Mr. Frederick C. Mosteller, Princeton, N. J.;

Dr. Theodor Samuel Motzkin, Hebrew University, Jerusalem, Palestine;

Dr. M. R. Neifeld, Beneficial Management Corp., Newark, N. J.;

Dr. Horace Wakeman Norton, U. S. Weather Bureau;

Mr. Norman Harding Painter, Massachusetts Institute of Technology;

Professor Benjamin Wissler Partlow, Madison College, Harrisonburg, Va.; 
Mr. Lester Charles Peach, Sergeant, U.S.A.;

Mr. Anthony Joseph Penico, University of Pennsylvania;

Mr. Phillip Irvine Peters, Union College, Barbourville, Ky.;

Miss Helen Bard Pettit, Mills College, Oakland, Calif.;

Mr. Robert I. Piper, So. California Telephone Company, Los Angeles, Calif.;

Professor Albert Roberts Poole, Montana State College, Bozeman, Mont.;

Professor Henry Jean Baptiste Putnam, Laval University;

Mr. Lloyd James Quaid, University of Minnesota;

Mr. Hugh Lawrence Quarles, Lieutenant Colonel, A.U.S.;

Mr. Russell Remage, Jr., Gassaway, W. Va.;

Miss Theresa M. Renner, Blackburn College, Carlinville, Ill.;

Mr. Franklin Victor Reno, Ballistics Research Laboratory, Aberdeen Proving Ground, Md.;

Dr. Nicholas A. Renzetti, U.S.N.O.T.S., Inyokern, Calif.;

Mr. Rodolfo Alfredo Ricabarra, University of La Plata;

Sister Mary Edmund Rice, Our Lady of Cincinnati College;

Professor Toivo E. Rine, Illinois State Normal University;

Professor Lawrence A. Ringenberg, University of Maryland;

Professor Leland Frederick Samuel Ritcey, United College, Winnipeg, Manitoba, Canada;

Mr. Emerson Richard Rohrer, Electronic Technician's Mate 2d Class, U.S.N.;

Dr. Jerome Michael Sachs, Chicago City College;

Professor Alberto Enrique Sagastume Berra, University of La Plata;

Mr. John Salerno, U. S. Coast and Goedetic Survey;

Mr. William Salkind, U. S. Department of Agriculture;

Mr. Charles Saltzer, Brown University;

Miss Augusta Louise Schurrer, University of Wisconsin;

Miss Mary Lurline Scott, National Bureau of Standards, Washington, D. C.;

Sister M. Georgianne Segner, LeClerc College, Belleville, Ill.;

Mr. Harold Douglas Seielstad, Lieutenant Commander, U.S.C.G.;

Mr. Carl Bryce Seligman, Ensign, U.S.N.R.;

Professor Paul B. Selz, Parsons College, Fairfield, Iowa;

Miss Charlotte B. Shapira, McLaughlin-Cara Associates, Cambridge, Mass.;

Mr. William Henry Shields, Philadelphia, Pa.;

Mr. Walt R. Simmons, U. S. Employment Service, Arlington, Va.;

Mr. Maurice Singer, U.S.A.;

Mr. Benjamin Slepin, Philadelphia, Pa.;

Mr. Ralph Jeffery Slutz, Princeton University;

Mr. Oliver M. Smart, U. S. Navy Inspection Service, Westinghouse Electric and Manufacturing Company, Essington, Pa.;

Professor Harold E. Smith, Junior College of Connecticut, Bridgeport, Conn.;

Mr. Henry Elmore Smith, Dickinson College, Carlisle, Pa.;

Professor Allen K. Snyder, Valley Forge Military Academy and Junior College, Wayne, Pa.;

Mrs. Ruth Cottingham Sorrells (Mrs. C. C.), Highland Park Senior High School, Dallas, Tex.;

Mr. George Springer, Brown University;

Mr. Robert Clarence Stewart, Washington and Jefferson College, Washington, Pa.;

Mrs. Ruth G. Sumner, Oakland High School, Oakland, Calif.;

Mr. Arthur Frank Svoboda, DePaul University; 
Mr. Taffee Tadashi Tanimoto, University of Chicago;

Mr. Benjamin Tannenbaum, Princeton University;

Mr. James Edgar Thompson, University of Minnesota;

Professor César Anselmo Trejo, University of La Plata;

Mr. Guy Z. Updike, College of the City of New York;

Professor Helen E. Vansant, Beaver College, Jenkintown, Pa.;

Professor Robert N. Varney, Department of Physics, Washington University;

Reverend Dunstan G. Velesz, Quincy College, Quincy, Ill.;

Professor Helen M. Walker, Teachers College, Columbia University;

Mr. Earl Eugene Wallick, Senior High School, Lakewood, N. J.;

Mr. Camille Jerome Weber, The Chase National Bank of the City of New York;

Miss Alma Kohl Weinstein, Houston, Tex.;

Dr. Charles A. Welsh, U. S. Department of Justice;

Miss Edith Freda Whitmer, Stephens College;

Mr. Wilbur James Widmer, Gibbs and Cox, Inc., New York, N. Y.;

Mr. Arthur Strong Wightman, Ensign, U.S.N.R.;

Mr. Roger Williams, Jr., Belle Works, DuPont Company, Charleston, W. Va.;

Miss Marcella Ann Yarosheski, St. Genevieve of the Pines Junior College, Asheville, N. C.;

Professor Theodore Otte Yntema, School of Business, University of Chicago;

Mr. John Wesley Young, Jr., University of Pennsylvania;

Professor Paul McClure Young, Miami University;

Miss Lillian Bertha Zarling, North Dakota State School of Forestry, Bottineau, N. D.

It was reported that the following had been elected to membership on nomination of institutional members as indicated:

Brooklyn College: Professor Merle L. Bishop;

Brown University: Dr. Chi-Teh Wang;

University of California: Messrs. Donald Marvin Adelman, Bjarni Jonsson, and Samuel Wolfenstein;

University of California at Los Angeles: Messrs. Milton Drandell and William C. Hoffman;

California Institute of Technology: Messrs. Donald A. Darling, Lincoln Kearney Durst, Verne Gilbert Robinson, and James G. Wendel;

University of Chicago: Miss Hilde Ruth Marlin, Mr. August Newlander, Jr.;

College of the City of New York: Mr. Julius S. Dwork;

Columbia University: Miss Azelle Brown, Mr. David James Dickinson, Professor Pao Lu Hsu, Messrs. Morris Newman and John Bert Secrist, Jr., Miss Miriam Skinner;

Harvard University: Messrs. Benjamin Nelson Moyls and John Joseph Sopka, Jr.;

University of Illinois: Messrs. Delbert Ferrel Atkins, Richard William Ball, Bernard

E. Howard, William A. Martin and Ernest A. Propes, Misses Mary Anice Seybold and Mary Frances Suter;

Indiana University: Messrs. Robert Earl MacKenzie and Samuel Schecter;

Institute for Advanced Study: Dr. Ky Fan;

Iowa State College: Mr. Russell Evan Carr;

State University of Iowa: Mr. Harlan Lowell Herrick;

Johns Hopkins University: Miss Fay Dalton Carpenter, Messrs. Raymond Huck,

Stanley Leonard Isaacson, and Sylvan Wallach;

Massachusetts Institute of Technology: Mr. Burton Mills; 
University of Michigan: Lieutenant William Boothby, Messrs. Arvid W. Jacobson, Edwin Henry Spanier, and Jesse Wright;

Michigan State College: Mr. Olan Trainer McMillan;

University of Minnesota: Miss Margaret Owchar;

Northwestern University: Mr. Richard Elton von Holdt and Mrs. Margaret Helen Stange;

University of Notre Dame: Reverend Henry F. DeBaggis;

Ohio State University: Messrs. H. Manfred Fliess and John Lewis Moll;

College of Saint Thomas: Mr. Donald John Lewis;

Stanford University: Mr. Andrew Heuer Van Tuyl;

Swarthmore College: Mrs. Elizabeth P. Allen;

Syracuse University: Mr. Helmut Aulbach;

University of Virginia: Mr. Victor La Rue Klee;

University of Washington: Mr. Harry Edward Kinerk;

Williams College: Dr. Arthur Smullyan;

University of Wisconsin: Messrs. Herman Jacob Cohen, Ottis William Rechard, Herbert John Ryser, Lee Robert White, and Russell Edward Wright;

Metropolitan Life Insurance Company: Mr. Edward A. Lew.

Professor T. G. Cowling of the University College of North Wales and Mr. Paul Vermes of The Grammar School, Farnborough, England, were admitted to the Society in accordance with the reciprocity agreement with the London Mathematical Society. Professor Alexander Markovich Ostrowski was admitted to the Society in accordance with the reciprocity agreement with the Swiss Mathematical Society.

The Secretary reported that, as of April 26, 1946, the total membership of the Society is 3,041 .

The following appointments by the President were reported: as representative of the Society at the inauguration of Wilson Martindale Compton as President of The State College of Washington on December 11, 1945, Professor M. S. Knebelman; as representative of the Society at the inauguration of Byron Sharpe Hollinshead as President of Coe College on December 14, 1945, Professor E. N. Oberg; as representative of the Society at the inauguration of Arthur Holly Compton as Chancellor of Washington University on February 22, 1946, Professor L. M. Blumenthal; as representative of the Society at the Fiftieth Annual Meeting of The American Academy of Political and Social Science on April 5-6, 1946, Professor Arnold Dresden; as representative of the Society at the Sesquicentennial Celebration of the University of North Carolina on April 12-13, 1946, Professor J. M. Thomas; as representative of the Society at an educational conference celebrating the inauguration of James Lewis Morrill as President of the University of Minnesota on April 23-25, 1946, Professor R. W. Brink; as representative of the Society at the inauguration of John Philip Wernette as President of The University 
of New Mexico on May 10, 1946, Professor Lincoln LaPaz; as representative of the Society on the Committee on Definitions of Electrical Terms of the American Institute of Electrical Engineers, Dr. H. W. Bode; as auditors of the Society's accounts for 1946, Professors T. F. Cope and A. E. Meder, Jr.; as a member of the Committee to Select Hour Speakers for Summer and Annual Meetings for 1946-47, Professor R. P. Agnew (committee now consists of Professors J. R. Kline, Chairman, R. P. Agnew, and C. C. MacDuffee); as a member of the Committee to Select Hour Speakers for Eastern Sectional Meetings for 1946-47, Professor A. W. Tucker (committee now consists of Professors T. R. Hollcroft, Chairman, Oystein Ore, and A. W. Tucker); as a member of the Committee to Select Hour Speakers for Western Sectional Meetings for 1946-47, Professor N. E. Steenrod (committee now consists of Professors R. H. Bruck, Chairman, Tibor Rado, and N. E. Steenrod); as a member of the Committee to Select Hour Speakers for Far Western Sectional Meetings for 1946-47, Professor Morgan Ward (committee now consists of Professors A. C. Schaeffer, Chairman, D. H. Lehmer, and Morgan Ward); as a Committee on Arrangements for the 1946 Summer Meeting at Cornell University, Professors B. W. Jones (Chairman), T. R. Hollcroft, W. T. Martin, J. B. Rosser, and R. J. Walker; as a committee to nominate representatives of the Society on the Policy Committee for Mathematics, Dean M. H. Ingraham (Chairman), Professors J. R. Kline and R. L. Wilder; as a Committee on Nomination of Officers and Members of the Council for 1947, Professors Saunders MacLane (Chairman), R. L. Jeffery, C. B. Morrey, Jr., Tibor Radó, and R. L. Wilder; as a member of the Committee on Printing Contracts, term to expire December 31, 1948, Professor J. M. Thomas (committee now consists of Professor R. M. Foster, Chairman, Dean M. H. Ingraham, and Professor J. M. Thomas); as a member of the Committee on Places of Meetings for 1946-48, Professor G. B. Price; as Chairman of the Committee on Places of Meetings for the year 1946, Professor C. R. Adams (committee now consists of Professors C. R. Adams, Chairman, G. B. Price, and W. T. Reid); as members of the Committee on Publicity, Professor R. J. Walker, 1946-48, Dr. J. M. Thompson and Professor J. B. Rosser, 1946-47 (committee now consists of Professors R. M. Foster, Chairman, J. B. Rosser, Dr. J. M. Thompson, and Professor R. J. Walker).

The Secretary reported that the following had been chosen as the voting representatives of editorial committees on the Council for the year 1946: Bulletin-Professor R. E. Langer; Transactions-Professor A. A. Albert; Colloquium Publications-Professor J. F. Ritt; Ameri- 
can Journal of Mathematics-Professor Hassler Whitney; Mathematical Reviews-Professor O. E. Neugebauer; Mathematical Surveys-Professor Nelson Dunford.

It was announced that Professor Will Feller is the representative of the Institute of Mathematical Statistics on the Policy Committee for Mathematics and that Professor Alonzo Church is the representative of the Association for Symbolic Logic. The representatives of the Society are Professors G. C. Evans, T. H. Hildebrandt, Marston Morse, and M. H. Stone. Professor J. R. Kline is an ex officio, nonvoting member of the committee and acts as secretary for the committee.

Professor J. L. Walsh was elected by the Council to fill the unexpired term of Professor J. D. Tamarkin as a member of the Mathematical Surveys Editorial Committee.

It was reported that Professor Nelson Dunford has been selected as the Chairman of the Mathematical Surveys Editorial Committee for the year 1946.

Certain invitations to deliver addresses were announced: Professor J. L. Doob for the 1946 Summer Meeting; Professor A. P. Morse for the 1946 Annual Meeting.

The Council adopted the following resolution on the death of Professor Harry Bateman:

The Council of the American Mathematical Society records with sorrow the untimely death of Harry Bateman, Professor of Mathematics, Physics, and Aeronautics at the California Institute of Technology. Born at Manchester, England, and trained at Cambridge University (where he was Senior Wrangler in the Mathematical Tripos of 1905), Bateman had the breadth of outlook and diversity of interests characteristic of the British mathematicians of his generation. The applications of mathematics were as important to him as the refinements of pure mathematics. A year at Göttingen and Paris (1905-06) stimulated his interest in the then recent theory of integral equations, in which he did his earliest extensive work. He came to the United States in 1910 (Bateman was a naturalized U. S. citizen); and after appointments at Bryn Mawr College and The Johns Hopkins University, accepted the professorship, which he held till his death, at the California Institute of Technology on its organization in 1917.

Bateman was a rare combination of erudition and creativeness. In the field of the differential equations and special functions of mathematical physics, his knowledge and power were unrivalled. He had "instant recall" in any subject he had ever studied, and could direct an enquirer through the voluminous literature of half a century at a moment's notice. His own analysis, in his writings and in his lectures, was characterized by a brilliant technique that always, somehow, produced the right operator or the ingenious transformation to dispose of the problem in hand with a minimum of labor. If his advanced students had any criticism of his lectures, it was the complimentary remark that Bateman's difficulty was his inability to distinguish between an easy problem and a hard one. 
Adequate notices of Bateman's research will appear elsewhere; it will suffice here to mention some of the topics which continued to interest him till the day of his death. Mathematical physics, particularly electrodynamics, fascinated him, with hydrodynamics, or perhaps sound, as a close second. Everything connected with wave motion, from sound to optics, was a lifelong interest. Here his knowledge was unequalled. When meteorology and seismology began to become mathematical Bateman added them to his repertory. In pure mathematics his interests centered in those subjectsgeometrical transformations, definite integrals, partial differential and integral equations, probability - where his extraordinary technical facility might have free play. Although he was familiar with the more refined types of analysis of the past forty years, and appreciated them, he seldom cared to work in them himself. Two major treatises, on definite integrals and on all the special functions hitherto discussed in mathematics, were laid aside under the urgency of war work.

In this Society, Bateman was a member of the Council (1924-26, 1944-45), Vice President (1935-36), and Gibbs Lecturer (1943). His membership in learned societies included the National Academy of Sciences, the American Philosophical Society, the Royal Society, London, and several others in the fields of his many interests.

Bateman was an incessant worker. His one ambition was the advancement of mathematical science. He was equally distinguished for his great scientific attainments, his unfailing gentleness, and his extreme modesty.

The Council accepted an invitation to meet at Princeton University on November 2, 1946. The Secretary reported that the Council had, by mail vote, accepted an invitation from Swarthmore College for the 1946 Annual Meeting. The Council canceled the meeting scheduled for October 26, 1946, in New York City. Times and places for meetings of the Society in the midwest and far west, respectively, were set as follows: November 29-30, 1946, at Iowa State College; November 30, 1946, at the University of California at Los Angeles.

The Council nominated Professor John von Neumann as a representative of the Society in the Division of Physical Sciences of the National Research Council for a three-year period beginning July 1, 1946. The other representatives of the Society for this three-year period will be: Professors A. B. Coble, Saunders MacLane, M. H. Stone, Oswald Veblen, and Dr. Warren Weaver.

The Council authorized the Policy Committee for Mathematics to give public expression to opinion in support of the Kilgore-Magnuson Bill.

Titles and cross references to the abstracts of papers read at the meeting follow below. Papers 1-10 were read in the section for Analysis, 11-19 in the section for Geometry and Topology, 20-28 in the section for Algebra, Statistics, etc., and 29-67 whose abstract numbers are followed by the letter $t$ were read by title. Paper 5 was read by Dr. Wasow, 9 by Dr. Szász, 13 by Professor Hall, 14 by Professor Kasner. Dr. Nachbin was introduced by Professor Antoni Zygmund, Professor Ringenberg by Professor D. W. Hall, Professor 
Samuelson by Professor T. R. Hollcroft, and Professor Shen by Professor E. J. McShane.

1. Bernard Epstein: Integral representation of solutions of the harmonic and wave equations. (Abstract 52-5-144.)

2. R. C. Buck: An extension of Carlson's theorem. (Abstract 52-5139.)

3. H. J. Zimmerberg: A class of definite integral systems. (Abstract 52-3-76.)

4. W. M. Chen: Distortion theorems in the theory of pseudo conformal mappings. (Abstract 52-5-142.)

5. K. O. Friedrichs and W. R. Wasow: On singular perturbations of nonlinear oscillations. (Abstract 52-5-149.)

6. Alexander Weinstein: On a generalization of an axially symmetric potential. (Abstract 52-5-171.)

7. Harry Pollard: The mean convergence of orthogonal series of polynomials. (Abstract 52-7-237.)

8. Herbert Federer: The $(\phi, k)$ rectifiable subsets of $n$-space. (Abstract 52-5-145.)

9. S. Minakshisundaram and Otto Szász: On absolute convergence of multiple Fourier series. (Abstract 52-5-156.)

10. R. P. Boas: The rate of growth of an analytic function determined from its growth on a sequence of points. (Abstract 52-7-230.)

11. Fred Supnick: Rectilinear deformation. (Abstract 52-5-213.)

12. P. R. Halmos: Invariant measures. (Abstract 52-5-151.)

13. D. W. Hall and J. W. T. Youngs: Comments on the cores of certain classes of spaces. (Abstract 52-5-202.)

14. Edward Kasner and John DeCicco: Comparison of union-preserving and contact transformations in space. (Abstract 52-5-187.)

15. Abraham Schwartz: Higher normal spaces for spaces of class greater than one. (Abstract 52-5-191.)

16. G. W. Whitehead: A generalization of the Hopf invariant. (Abstract 52-5-215.)

17. J. H. Roberts: Open transformations and dimension. (Abstract 52-5-210.)

18. Hing Tong: Ideals of normed rings associated with topological spaces. Preliminary report. (Abstract 52-7-241.)

19. I. E. Segal: The spectrum of a commutative subalgebra of a group algebra. Preliminary report. (Abstract 52-5-131.)

20. I. S. Cohen: Groups and rings of finite rank. Preliminary report. (Abstract 52-5-110.)

21. Marshall Hall: The sum of continued fractions. (Abstract 52-355.) 
22. A. T. Brauer: On a theorem of M. Bauer. (Abstract 52-5-108.)

23. I. M. Sheffer: Note on multiply-infinite series. (Abstract 52-5132.)

24. Will Feller: The law of the iterated logarithm for identically distributed random variables. (Abstract 52-5-196.)

25. Casper Goffman: Measures of fluctuation of a variable mean. Preliminary report. (Abstract 52-5-197.)

26. Ira Rosenbaum: Hegel's observations on the differential and integral calculus and its foundations. (Abstract 52-3-95.)

27. C. A. Truesdell: On Sokolovsky's "momentless shells." (Abstract 52-3-87.)

28. Garrett Birkhoff: Symmetric Lagrangian systems. (Abstract 527-242.)

29. Reinhold Baer: Projectivities with fixed points on every line of the plane. (Abstract 52-5-181-t.)

30. Richard Bellman: Stability of difference equations. (Abstract 52-7-228-t.)

31. Garrett Birkhoff and L. J. Burton: A weakening of the Hölder conditions for Newtonian force fields. (Abstract 52-5-137-t.)

32. A. T. Brauer and Gertrude Ehrlich: On the irreducibility of certain polynomials. (Abstract 52-5-109-t.)

33. B. L. Brown and N. H. McCoy: Radicals and subdirect sums. (Abstract 52-3-54-t.)

34. Nathaniel Coburn: Pressure-volume relations and the geometry of the net of characteristics in two-dimensional supersonic flows. (Abstract 52-5-174-t.)

35. M. A. Coler: Observations on primes. (Abstract 52-5-111-t.)

36. H. S. M. Coxeter: $A$ new extreme form in seven variables. (Abstract 52-5-112-t.)

37. H. S. M. Coxeter: The content of the general regular polytope. (Abstract 52-5-182-t.)

38. Arnold Emch: New properties of quadrics with umbilics based upon their stereographic projections. (Abstract 52-5-185-t.)

39. Will Feller: A limit theorem for random variables with infinite moments. (Abstract 52-5-195-t.)

40. E. E. Floyd: On the extensions of homeomorphisms on the interior of a two cell. (Abstract 52-5-200-t.)

41. K. O. Friedrichs: An inequality for potential functions. (Abstract 52-5-146-t.)

42. K. O. Friedrichs: On a theorem of Lichtenstein. (Abstract 52-5147-t.) 
43. K. O. Friedrichs: On the boundary value problems of the theory of elasticity and Korn's inequality. (Abstract 52-5-148-t.)

44. R. A. Good: On the construction of clusters. (Abstract 52-5116-t.)

45. W. H. Gottschalk: Almost periodicity, equi-continuity and total boundedness. (Abstract 52-5-201-t.)

46. G. W. Mackey: On convex topological linear spaces. (Abstract 52-7-235-t.)

47. Leopoldo Nachbin: On linear expansions. I. (Abstract 52-5158-t.)

48. Isaac Opatowski: Markoff chains with variable intensities: average duration of transition. (Abstract 52-5-199-t.)

49. L. A. Ringenberg: On the extension of interval functions. (Abstract 52-5-161-t.)

50. Ira Rosenbaum: Hegel, mathematical logic, and the foundations of mathematics. (Abstract 52-5-194-t.)

51. H. E. Salzer: Coefficients for facilitating the use of the Gaussian quadrature formula. (Abstract 52-5-178-t.)

52. H. E. Salzer: Further empirical results on tetrahedral numbers. (Abstract 52-5-126-t.)

53. P. A. Samuelson: A connection between the Bernoulli and Newton iterative processes. (Abstract 52-3-84-t.)

54. P. A. Samuelson: Computation of characteristic vectors. (Abstract 52-3-85-t.)

55. P. A. Samuelson: Generalization of the Laplace transform for difference equations. (Abstract 52-3-86-t.)

56. Robert Schatten (National Research Fellow): On projections with bound 1. (Abstract 52-5-164-t.)

57. I. E. Segal: Representation of certain commutative Banach algebras. (Abstract 52-5-130-t.)

58. Y. C. Shen: Interpolation to certain analytic functions by rational functions. (Abstract 52-5-165-t.)

59. P. A. Smith: Foundations of Lie groups. (Abstract 52-5-166-t.)

60. A. C. Sugar: The use of invariant inverted matrices for the simultaneous approximate solution of classes of boundary value problems. Preliminary report. (Abstract 52-7-249-t.)

61. Fred Supnick: $A$ class of functions with associated circle manifolds. (Abstract 52-5-167-t.)

62. Fred Supnick: Equivalent rectilinear graphs. (Abstract 52-5214-t.)

63. Fred Supnick: On certain limiting sequences of polygons. (Abstract 52-5-168-t.) 
64. Fred Supnick: On Vitali's covering theorem. (Abstract 52-5169-t.)

65. Y. C. Wong: Contributions to the theory of surfaces in a 4-space of constant curvature. (Abstract 52-5-192-t.)

66. Y. C. Wong: Scale hypersurfaces for conformal-Euclidean space. (Abstract 52-5-193-t.)

67. H. J. Zimmerberg: Two general classes of definite integral systems. (Abstract 52-5-173-t.)

T. R. HollCrofT, Associate Secretary 